Materials and methods. To study the effect of Cytoflavin on parameters of systolic left ventricular function in acute myocardial infarction. 46 patients with standard therapy received the drug Cytoflavin (Polysan, St.Petersburg, Russia) intravenously $20 \mathrm{ml}$ of the solution diluted in $250 \mathrm{ml} 5 \%$ glucose solution, 1 times a day 30 minutes before coronary artery recanalization; 60 patients (control group) received only standard therapy. The drug's effectiveness was evaluated in terms of systolic left ventricular function: ejection fraction, end-diastolic volume, end-systolic volume.

The introduction of Cytoflavin patients contributed to an increase in ejection fraction of the left ventricle of $7.9 \%$ compared to the same indicator in the patients of the control group, reduced end-diastolic and end-systolic volume of the left ventricle by $10.6 \%$ and $17.9 \%$ respectively on day 7 of hospitalization $(p \leq 0,05)$. Addition to standard therapy with Cytoflavin significantly reduced the level of troponin I in patients with acute myocardial infarction on day 7 for $81 \%$ relative to the control, the activity of creatine kinase $-35 \%(p \leq 0,05)$.

The inclusion of Cytoflavin in the treatment of patients with acute myocardial infarction should be considered as pathogenetically justified clinically justified and promising.

Intravenous drip for patients with acute myocardial infarction Cytoflavin 30 minutes before coronary artery recanalization on the background of standard therapy promotes the positive dynamics of systolic left ventricular function with increased ejection fraction of the left ventricle, reducing end-diastolic and end-systolic volume of the left ventricle in comparison with similar indicators of control group on day 7 of hospitalization. Inclusion in standard therapy of acute myocardial infarction succinaldehyde of the drug Cytoflavin significantly reduces the level of troponin I and activity of creatine kinase in the blood of patients with myocardial infarction on day 7 relative to the patients of the control group.

\title{
REFERENCES
}

Dorovskikh V.A., Borodin E.A., Lee O.N., Simonova N.V., Starberg M.A., Dorovskikh Yu.V. Comparative efficiency of different antioxidants during cold exposure and overheating. Blagoveshchensk; 2016 (in russian).

Dorovskikh V.A., Borodin E.A., Shtarberg M.A., Shtarberg S.A., Egorov K.E. Phospholipids as antiatherosclerotic drugs. In book: Lipoproteins and atherosclerosis. Abstracts of the Symposium devoted to the 110 anniversary from the birthday of academician N.N. Anichkov «Lipoproteins and atherosclerosis». Moscow; 1995: 41-46 (in russian).

Dorovskikh V.A., Tseluyko S.S., Simonova N.V., Anokhina R.A. In the world of antioxidants. Blagoveshchensk, 2012 (in russian).

Landyshev Ju.S., Dorovskikh V.A., Tseluyko S.S., Lazutkina E.L., Tkacheva S.I., Chaplenko T.N. Bronchial asthma. Blagoveshchensk, 2010 (in russian).

Landyshev Ju.S., Dorovskikh V.A., Chaplenko T.N. Drug Allergy. St-Petersburg, 2010 (in russian).

Simonov V.A., Simonova N.V. Method of correcting lipid peroxidation in animal white muscle disease. Krasnoyarsk, 2006 (in russian).

Simonova I.V., Dorovskikh V.A., Simonova N.V., Shtarberg M.A. Non-specific preventive measures against respiratory diseases of nursery age children. Far Eastern Medical Journal 2009; 3:56-58 (in russian).

Simonova N.V. Herb extracts and oxidative stress in the ultraviolet irradiation conditions. Agricultural research Journal 2011; 8:23-26 (in russian).

Simonova N.V., Dorovskikh V.A., Anokhina R.A. Medicinal plants of the Amur region. Blagoveshchensk; 2016 (in russian).

Simonova N.V., Dorovskikh V.A., Shtarberg M.A. Effect of adaptogens of plant origin on the intensity of the processes of peroxidation of lipids of membranes under conditions of ultraviolet irradiation. Far Eastern Medical Journal 2010; 2:112-115 (in russian).

Simonova N.V., Dorovskikh V.A., Simonova N.P. Ultraviolet radiation and oxidative stress. The possibility of phitocorrection. Blagoveshchensk, 2014 (in russian).

Simonova N.V., Dorovskikh V.A., Li O.N., Shtarberg M.A., Simonova N.P. Tincture of medicinal plants and oxidative stress in the conditions of cold influence. Bulletin physiology and pathology of respiration 2013; 48:76-80 (in russian).

Simonova N.V., Lachin A.P, Simonova N.P. Efficiency in correction phytopreparations of lipid peroxidation of biomembranes the background ultraviolet radiation. Vestnik Krasnoyarsk state agrarian University 2010; 5:95-98 (in russian).

Zenkov N.K., Kandalintseva N.V., Lankin V.Z., Men’shchikova E.B., Prosenko A.E. Phenolic Bioantioxidant. Novosibirsk: SB RAMS; 2003 (in russian).

UDC 615 DOI 10.22448/AMJ.2017.3.56-57

\section{SUCCESSFUL TREATMENT OF JUVENILE RHEUMATOID ARTHRITIS WITH GENETIC ENGINEERING BIOLOGICAL DRUGS}

\author{
Pogrebnaya M.V., Eremenko S.I., Abuldinov A.S., Abuldinova O.A.
}

\author{
Amur State Medical Academy, Blagoveshchensk, Russia
}

Abstract. This article presents a case of successful treatment with genetic engineering biological drugs of juvenile rheumatoid arthritis. The authors draw attention to the fact that early onset of active basic treatment of juvenile rheumatoid arthritis prevents the progression of joints destruction and disability of the patient.

Key words: juvenile rheumatoid arthritis, genetic engineering biological drugs.

56 Амурский медицинский журнал №3 (19) 2017 
Immunosuppressive therapy is used in the pathogenetic treatment of rheumatoid arthritis. Methotrexate for rheumatoid arthritis is considered the current gold standard first line treatment. In recent years, the combination of methotrexate and genetic engineering biological drugs is used with high efficiency.

Patient S., 18 years old, was admitted on 24 March 2016 in the rheumatology department of the Amur regional clinical hospital with clinical diagnosis: Rheumatoid arthritis seropositive, deployed stage, activity I, non-erosive (radiographic stage 1), ACCP (-), FCl, complications: secondary amyloidosis with renal impairment, osteoporosis with pathological fractures.

III since 2006, when first appeared pain in the ankle and knee joints. Over the next years the condition worsened, joined by pain in the wrist joints, there was swelling of the knee and limitation of motion in the aforementioned joints. Was examined in the cardiology department of the Amur regional children's clinical hospital. Diagnosis: Juvenile rheumatoid arthritis. Treatment with prednisolone at a dose of $30 \mathrm{mg} /$ day, showed a slight effect. In 2007, the treatment pulse therapy with methylprednisolone $1000 \mathrm{mg} \mathrm{No3}$, cyclophosphamide at a dose of $1000 \mathrm{mg}$ No2 (1 per month), prednisone $1.5 \mathrm{mg} / \mathrm{kg} /$ day. The patient constantly took methotrexate at a dose of $10 \mathrm{mg} / \mathrm{week}$ in combination with folic acid. In 2008, there were pronounced swelling on the face in the periorbital area and on the feet. The examination revealed massive proteinuria, hydrothorax and hydropericardium. Sent to Moscow to Russian children's clinical hospital for further examination, diagnosis and determining further management of patients. Had a biopsy of the kidneys, it results diagnosis: Juvenile rheumatoid arthritis. Secondary renal amyloidosis. In 2012, the RAMS Institute of Rheumatology diagnosis of rheumatoid arthritis, secondary amyloidosis of the kidneys confirmed. Since 2014 receives infliximab at a dose of $200 \mathrm{mg} 1$ every 8 weeks. The present hospitalization is planned in connection with the achievement of the age of eighteen and the transition under the supervision of an adult rheumatologist.

By results of additional methods of examination of clinical, laboratory and radiological disease activity is not marked at the moment. He continues to receive treatment of methotrexate $15 \mathrm{mg}$ per week in combination with folic acid $5 \mathrm{mg}$ per week, infliximab $200 \mathrm{mg} 1$ every 8 weeks via intravenous infusion pump.

The interest of the case lies in the fact that early active basic treatment of juvenile rheumatoid arthritis prevented the progression of destruction of joints, disability of the patient, to neutralize the manifestations of amyloidosis and nephrotic syndrome, improving quality of life in general.

1. Nasonov E.L. Clinical guidelines. Rheumatology. M.: GEOTAR-Media, 2011.-758 p.

2. Nasonov E.L, Nasonova V.A. Rheumatology: National leadership. M.: GEOTAR-Media, 2008.-720 p.

3. Smolen J.S., Lamdewe R., Breedveld F.C. et al. EULAR recommendations for the management of rheumatoid arthritis with synthetic and biological disease-modifying anti-rheumatic drugs. Ann Rheum Dis 2010; 69: 964-975.

DOI 10.22448/AMJ.2017.3.57-57

\title{
THERAPEUTIC EFFECT OF SHIKONIN ON COLLAGEN-INDUCED ARTHRITIS BY DOWN-REGULATION OF TH1 RESPONS- ES AND INDUCTION OF TH2 AND TREG RESPONSES
}

\section{Qiaomei Dai, Meiqiao Wang, Mengting Lu, Hui Liang, Yanqi Shang, Xinxin CHen}

\author{
Department of pathology, Heilongjiang University of Chinese Medicine, Harbin, China
}

\begin{abstract}
Objective: To investigate the therapeutic effect of shikonin on collagen-induced arthritis (CIA) and its influence on Th1/Th2/Treg balance.Methods: Shikonin were given to mouse by oral administration before the onset of $\mathrm{ClA}$, and MTX was used as positive control drug. The arthritis response was monitored visually by macroscopic scoring. Joint swelling were measured by micrometer measurements of mouse. RT-PCR was employed to determine the mRNA expression of cytokines and transcription factors in patella with adjacent synovium in CIA mouse. Histology of knee of CIA was used to assess the occurrence of cartilage destruction and bone erosion. The expression of regulatory $T$ cells on lymph node of CIA was tested by immunohistochemistry. Western blotting was used to detect the expression of FOXP3 in spleen of CIA. Results: Shikonin treatment suppressed the macroscopic score and incidence of arthritis. A more pronounced improvement on the advancement of histology was found in mouse treated with shikonin on $\mathrm{CIA}$, which reduce cellular infiltrates in the synovial tissue and provide protection against cartilage destruction. Swelling of hind paws were delayed with shikonin when compared to controls. Moreover, the expression of Th1 cytokines (IL-18, IL-12, TNF-a) was greatly inhibited both in the synovial tissue and in the articular cartilage in treated groups compared with those in control groups. The mRNA levels of Th2 cytokines(IL-10), however, were up-regulated after shikonin treatment. The expression of factor (Foxp3,TGF-b) in the synovial tissue and in the cartilage was up-regulated after shikonin treatment. T-bet mRNA levels were decreased in shikonin group compared with control group. The expression of Foxp3 protein in spleen was up-regulated after shikonin treatment through Western blotting. The expression of Foxp3 in lymph node has no statistical significance compared with control group through immunohistochemistry. Conclusion: Shikonin has therapeutic effects on collagen induced arthritis. Shikonin treatment can inhibit Th1 cytokines expression and induce Th2 cytokines(IL-10) and TGF-b expression, which may be mediated not only by inhibiting Th1 responses through a T-bet dependent mechanism, but also by inducing cytokins such as IL-10 and TGF-b through a Treg-dependent mechanism.
\end{abstract}

Key words: Shikonin collagen induced arthritis regulatory $T$ cells $T$ helper cells 1 T helper cells 2 